\title{
The effect of tilt angle on the performance of evacuated tube solar air collector: experimental analysis
}

\author{
Vishal Dabra $^{1 *}$, Laxmikant Yadav², Avadhesh Yadav ${ }^{3}$ \\ ${ }^{1 *}$ Department of Mechanical Engineering, P.I.E.T., Haryana, INDIA \\ ${ }^{2}$ Department of Mechanical Engineering, A.K.G., Ghaziabad, INDIA \\ ${ }^{3}$ Department of Mechanical Engineering, N.I.T, Kurukshertra, INDIA \\ ${ }^{1 *}$ Corresponding address: E-mail: vishaldabra16787@gmail.com, Tel. No.: +919416259010.
}

\begin{abstract}
The evacuated tube solar air collector had different collector tilt angles from the horizontal with the one inclined at $30^{\circ}$ and $45^{\circ}$. Experimental results revealed that tilt angle had significant influence on the thermal performance of the evacuated tube solar air collector along with or without reflector. Experiments also showed that, for $30^{\circ}$ tilt angle evacuated tube solar air collector with reflector had better thermal performance then the $45^{\circ}$ tilt angle evacuated tube solar air collector with or without reflector. This indicated that increasing collector tilt angle had no positive effect on the thermosyphon phenomenon inside the evacuated tubes.
\end{abstract}

Keywords: Evacuated tube, solar air collector, thermal Performance, tilt angles, reflector.

DOI: http://dx.doi.org/10.4314/ijest.v5i4.9

\section{Introduction}

Rapid increased energy prices and the continuous reduction of the Earth's conventional fuels resources as well as the increased world-wide global warming have been the motivation for the recent growing interest in alternative sources of energy, such as solar energy. The development of renewable energy technologies is important for the future of a balanced global energy economy. The non-conventional sources of energy are capable of solving all above problems of energy. The renewable energy fulfills the gap between mounting energy demand and diminishing supply of conventional sources of energy. Need of clean environment and the increase in demand of more healthy and hygienic food-products encourages the use of renewable energy in industrial production and domestic processes. Solar Energy is the best solution to avoid energy crisis. To save conventional energy sources and to protect the environment, solar energy is the best aspect (Zhiqiang, 2005).

The optimum inclination angle for a thermosyphon solar water heater varies $0^{0}$ to $10^{0}$ for maximum solar fraction in northern region and varies $0^{0}$ to $20^{\circ}$ for southern region (Shariah et al., 2001). This investigation showed that the performance of the vacuum tube collector was better than flat plate collector. Vacuum tube collector was independent of climatic variations. (Adsten et al., 2002). Tang et al. (2009) stated that T-type collectors annually collect slightly more radiation than H-type collectors. For most areas in China, the site latitude larger than $30^{\circ}$, T-type collectors should be installed with a tilt-angle about $10^{\circ}$ less than the site latitude, whereas for H-type collectors without DFR( Diffuse flat reflector), the reasonable tilt-angle should be about $20^{\circ}$ less than the site latitude. Ayompe et al. (2011) presented performance comparison of the FPC( Flat plate collector) and ETC (Evacuated tube collector) respectively on daily, monthly and yearly basis and found that the annual average collector efficiencies were $46.1 \%$ and $60.7 \%$ but the whole system efficiencies were $37.9 \%$ and $50.3 \%$ respectively. Chow et al. (2011) had shown that two phase closed thermosyphon system performed better than single phase open thermosyphon system.

Economically both the systems were never compete the flat plate collector but suitable for the applications of high temperature demand. Hossain et al. (2011) found the performance of a thermosyphon solar water heater through simulation system. Positive collector angle was used for northern hemisphere and for space heating steep tilt angles were the right choice. Solar water heater 
with a syphon system found $18 \%$ higher characteristics efficiency than the conventional system due to reduce heat loss for the thermosyphon solar water heater. Tang et al. (2011) showed that SWH-22 and SWH-46 circulates water smoothly in the morning to afternoon but in the afternoon SWH-22 water circulation was good as compare to the SWH-46 and also increase the inlet water temperature. This indicated that SWH-46 had no positive effect on the thermosyphon circulation of the water inside tubes. Lamnatou et al. (2012) investigated the evacuated tube solar air collector for drying experiments of apples, carrots and apricots which included measurements for the determination of the collector efficiency and showed that agriculture products were drying without pre-heating.

$\mathrm{Xu}$ et al. (2012) studied the thermal performance of all-glass evacuated solar collectors with air as heat transfer fluid under dynamic outdoors conditions and found the results which was helpful for the designers to find out the output energy and thermal efficiency of solar air collectors according to the weather resources. Yadav and Bajpai (2012) experimentally investigated the performance of an evacuated tube and flat plate solar collector at different flow rates of air. Results found that evacuated tube solar collectors have better thermal performance than flat-plate solar collectors at different flow rates. Yadav and Bajpai (2012) experimentally investigated a solar-powered air heating system using one-ended normal evacuated tubes for heating purpose. Experiment was performed in both parallel and counter flow of air and results found that high flow rate and counter flow gave best performance. Zambolin and Col. (2012) presented an experimental validation of one ended evacuated tube collector with and without reflector. The results revealed that optical efficiency shows better with wide range of incident angle by using reflectors and east-west tube alignment were preferred for balancing the heat production between summer and winter season.

The objective of this paper is the experimental investigation of thermal performance of evacuated tube solar air collector with effect of tilt angle. For this reason, an experimental system has been installed at NIT Kurukshetra, India $\left[29^{\circ} 58^{\prime}\right.$ (latitude) North and $76^{\circ} 53^{\prime}$ (longitude) East].

\section{Experimental Set-Up}

The aim of this experimental work is to study the thermal performance of an evacuated tube solar air collector with different tilt angles and reflector. The test sections of solar air collector based on one ended glass evacuated tube is shown in Figure 1. It consist a header with fifteen one ended glass evacuated tube which are mounted on an adjustable stand and attached to a heat exchanger (Radiator). The length of the evacuated tube is $1500 \mathrm{~mm}$. Outer diameter of the evacuated tube and absorber tube are $47 \mathrm{~mm}$ and $37 \mathrm{~mm}$, respectively. Each evacuated tube filled with water which acts as heat carrying medium that's why it is called primary working fluid. The collector is inclined with an angle of $30^{\circ}$ and $45^{\circ}$ relative to horizontal. A radiator fan is used to blow the air over the heat exchanger (radiator pipes) and fins of heat exchange for absorbing heat. Air acts as secondary working fluid.

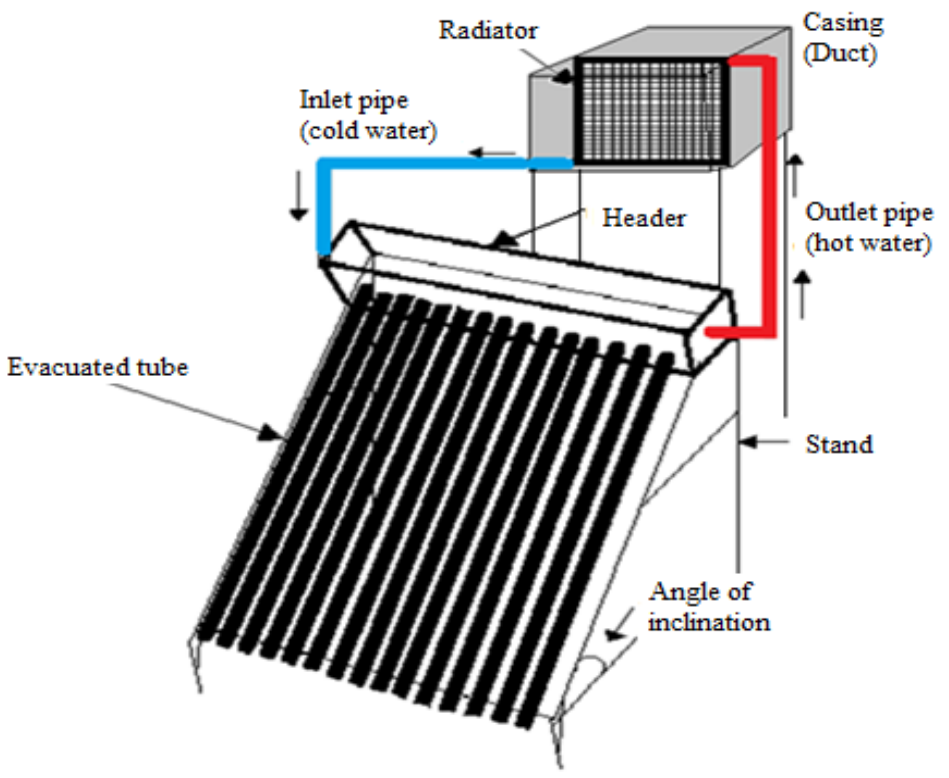

Figure 1. Schematic diagram of the evacuated tube solar air collector. 


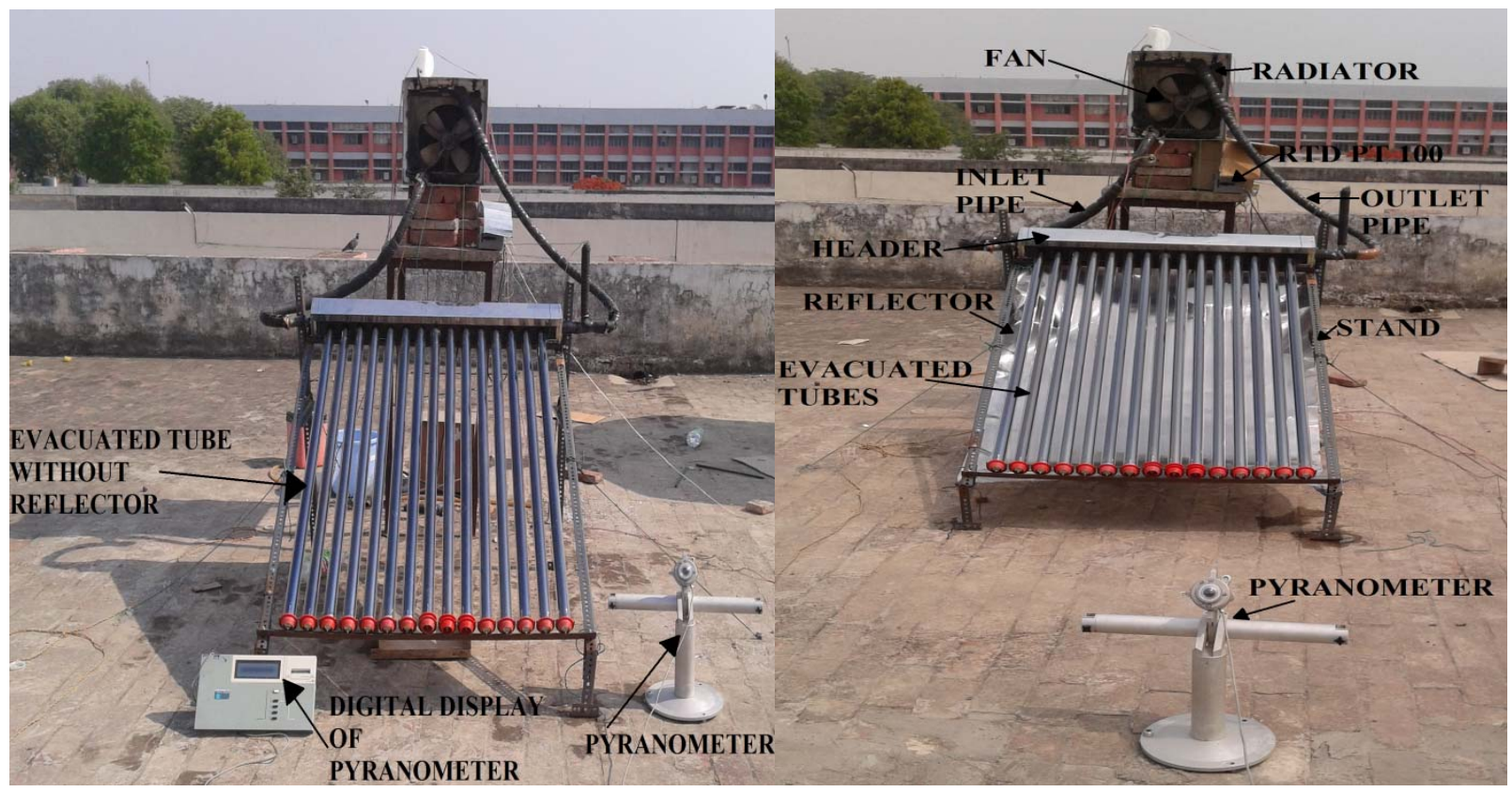

(a)

(b)

Figure 2. Photograph of experimental setup at tilt angle (a) without reflector, (b) with reflector

The system consists of following parts:

\subsection{Evacuated tubes}

Each evacuated tube consists of two glass tubes made from extremely strong borosilicate glass. The outer tube is transparent allowing light rays to pass through with negligible reflection. The inner tube is coated with a special selective coating (Al-N/Al) which features excellent solar radiation absorption and negligible reflection properties. The top of the two tubes are fused together and the air contained in the space between the two layers of glass is pumped out while exposing the tube to high temperatures. This "evacuation" of the gasses forms a vacuum, which is an important factor in the performance of the evacuated tubes. The evacuated tube used in this system is shown in Figure 3(a) and 3(b). These evacuated tubes are filled with water for thermosyphon.

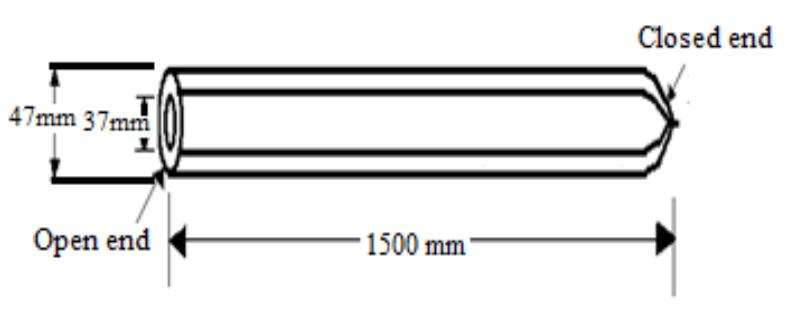

(a)

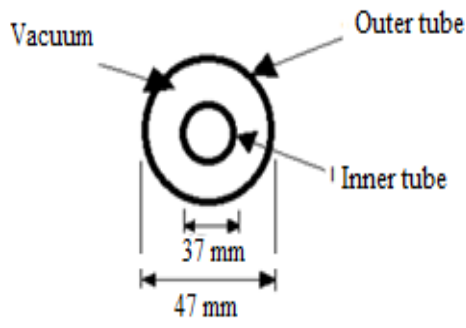

(b)

Figure 3. (a) Schematic diagram of one ended evacuated tube along the length (b) Schematic diagram of cross-section of one ended evacuated tube

\subsection{Header}

The header used in this system is shown in Figure 4(a). The outer body of the header and square pipe inside the header is made up of the steel. The pipe contains fifteen holes in which the evacuated tubes are attached. Open end of the evacuated tubes are fitted in these holes and the closed ends are supported by the frame. Insulation (glass wool) is provided between outer steel body and the inner square pipe for reducing the heat losses from the header to atmosphere which is shown in Figure 4(b). 


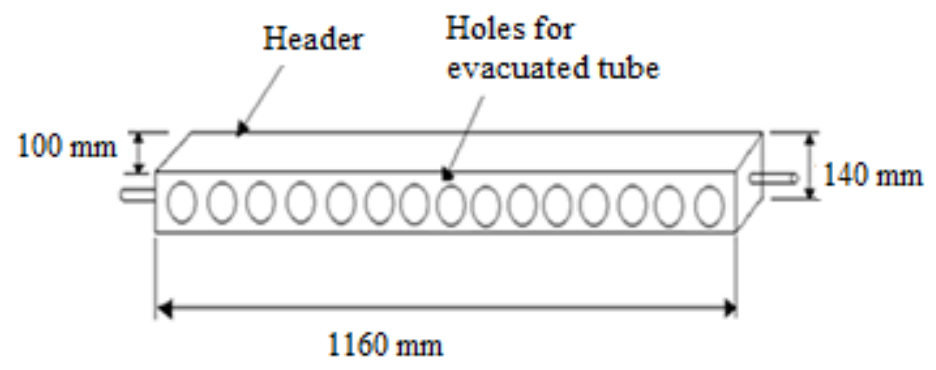

(a)

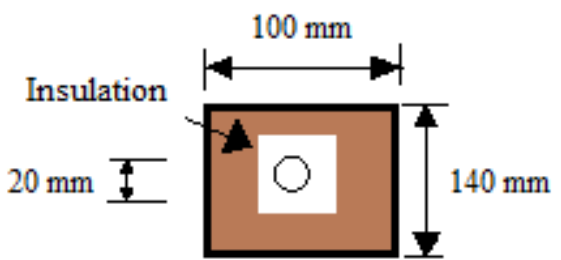

(b)

Figure 4. Schematic diagram of (a) complete header, (b) cross-sectional view of header

\subsection{Heat exchanger (Radiator)}

The heat exchanger used in this system is shown in Figure 5(a) and outer casing in which heat exchanger is placed shown in Figure 5(b). Radiators are thermal exchange devices used to transfer heat from one medium to another. They work by circulating steam or liquid through exposed metal pipes. Radiators are constructed of the same basic components, though they can vary greatly in size and appearance. The tubes make up the radiator's core. Tubes are often coated on the inside and outside and are most often made from aluminum, but they can also be copper or brass. The purpose of radiator fins is to increase surface area, making the heat transference more effective.

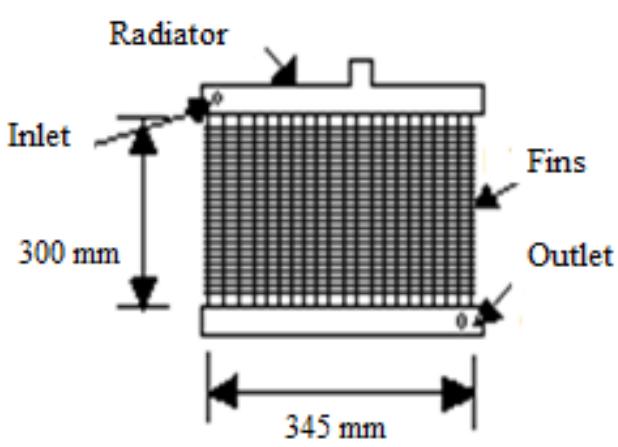

(a)

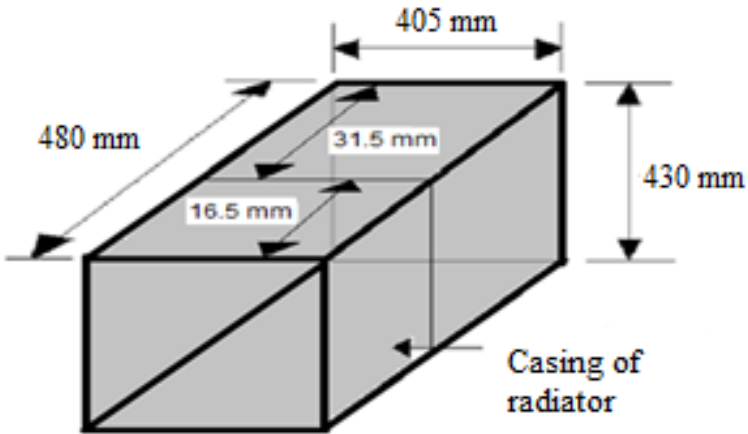

(b)

Figure 5. Schematic diagram of (a) radiator and (b) its casing (duct).

\subsection{Reflectors}

One GI sheet (galvanized) of $1550 \times 1200 \mathrm{~mm}^{2}$ size made up of mild steel coated with zinc was used as reflector for enhance the thermal performance of evacuated tube solar air collector.

\section{Measuring Devices}

The different parameters are measured for calculating the thermal performance of the evacuated tube solar air heater are the following:

1. The inlet and outlet temperature of the air

2. Solar radiation intensity

3. Air flow rate

RTD PT100 thermocouples are used to measure the temperatures at different points. The thermocouples are connected with a digital temperature indicator that gives the temperature with a resolution of $011^{\circ} \mathrm{C}$. The solar radiation intensity is measured during the day using a Pyranometer which is supplied by CM11 Kipp and Zonen, Holland. The air flow rate was measured at the beginning of experimental work. An AM-4201 anemometer is used to measure the velocity of air with an accuracy of $0.1 \mathrm{~m} / \mathrm{s}$.

\section{System Operation}

Initially, the tap water was supplied to the evacuated tube solar air collector and then expose to the sun. The steady state condition temperature is noted. This tap water circulates by thermosyphon from evacuated tube to header and header to heat exchanger (Radiator) as shown in Figure 7. The heat exchanger is surrounded by perfectly insulated duct. It is equipped with a set 
of pipe connections, one located near the top of the heat exchanger and one located near the bottom. Instrumentation openings are also required. A RTD PT100 (Resistance Temperature Detector) that measures the inlet and outlet temperatures of the air across the heat exchanger, controls the flow of air in the system by regulating switch.

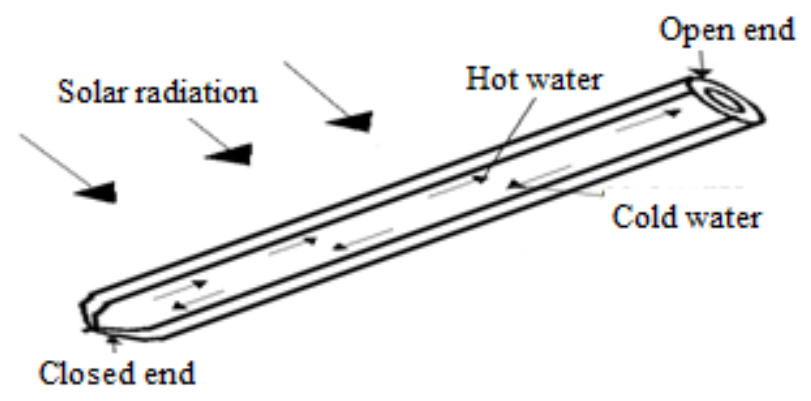

Figure 6. Thermosyphon phenomenon inside the evacuated tube

Stagnation is a condition that may occur when the system is deactivated while working fluid is contained in the collector during periods of solar insolation. A stagnant region is observed near the closed end of the evacuated tube. Stagnant region is occurred when aspect ratio (L/r) is 10 (Morrison et al., 2004). For example, on a sunny day stagnation temperatures in an evacuated tube collector can exceed $200^{\circ} \mathrm{C}$, leading to vaporization of the transport fluid within the collector and excessive pressure build up in the system piping. In the case of a closed-loop system, it is important to ensure that all components in the collector loop can withstand these temperatures and pressures. A pressure relief valve and an expansion tank are used to protect the system components and control devices. The piping network is insulated by a layer of polyurethane foam in order to minimize heat losses. A digital anemometer is included in the circuit for the purpose of measuring the flow rate at inlet and outlet of the system. Finally, solar radiation was measured by a pyranometer, connected to a data logger. Readings were taken manually after every one hour at stable flow conditions. The temperature readings were taken from the RTD.

\section{Performance Analysis}

For analyzing the performance of the experimental setup is expressed (Ma et al., 2010).

Surface area of solar collector, $\mathrm{A}=2 \mathrm{DL}$

Amount of heat gain by working fluid $=\mathrm{m} \mathrm{C}_{\mathrm{p}}\left(\mathrm{T}_{\text {out }}{ }^{-} \mathrm{T}_{\text {in }}\right)$

The thermal performance of the glass evacuated tube solar collector can be estimated by the solar collector efficiency factor, $\eta$, which is defined as the ratio between the net heat gain and the solar radiation energy based on area of solar collector A.

$$
r_{i}=\frac{\text { valimanimi }}{i_{0} h}
$$

\section{Results and Analysis}

The experiments were carried out during some selected clear sky days from 1 April 2012 to 16 May 2012. The experimental data are recorded at an interval of $1 \mathrm{hr}$ during the daytime. In this research work influence of tilt angle on the evacuated tube solar collector was observed and shown in the form of two different cases as following.

Case 6.1: Evacuated tube solar air collector at $45^{\circ}$ without and with reflector

The evacuated tube solar air collector was exposed to solar radiation one hour before the readings were taken. Figure 7 shows that solar radiation increases from 9:30 hr to $13: 30 \mathrm{hr}$ and after that it decreases. Initially obtained temperature difference of air is $4.8^{\circ} \mathrm{C}$ because of heat gained by fluid (water) inside the collector. It start increased up to 13:30 hr due to increase in solar intensity, after that it decreases with decrease in solar intensity. After 15:30 sharp decrease in the temperature difference of the air and at 16:30 it become nil due to decrease in the thermosyphon phenomenon. In this case, the maximum temperature difference of air was $12.4^{\circ} \mathrm{C}$ at $13: 30 \mathrm{hr}$, solar intensity was also maximum at this time. 


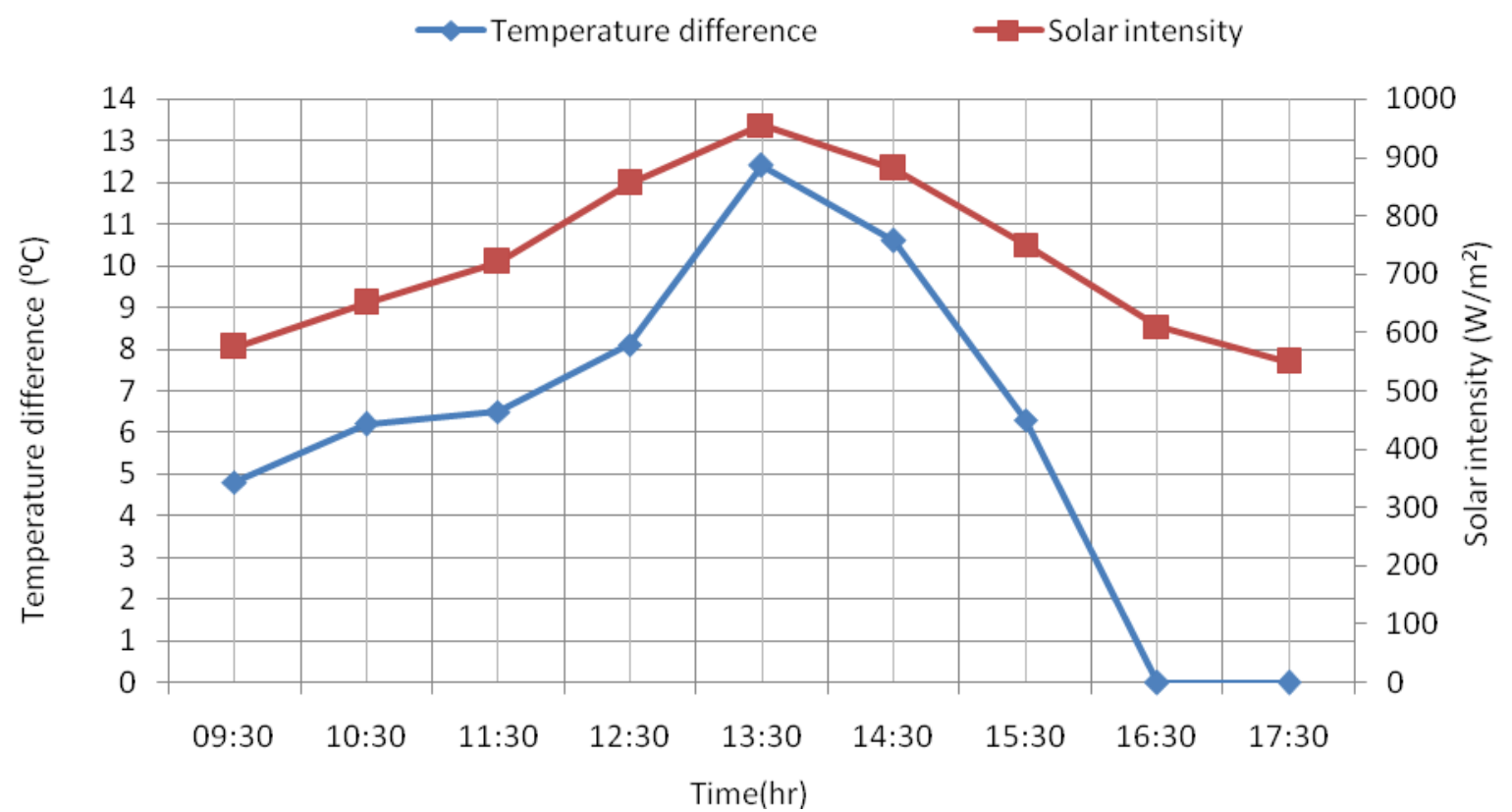

Figure 7. Variation of temperature difference of air along with variation of solar intensity for solar air collector without reflector at 45 tilt angle

Figure 8 shows that solar radiation increases from 9:30 hr to $13: 30 \mathrm{hr}$ and after that it decreases. Initially obtained efficiency is 0.4088 because of small temperature difference of the air and then it start increased up to 13:30 hr due to increase in temperature difference of air, after that it decreased with decrease in temperature difference of the air. In this case, the maximum efficiency was 0.6359 at 13:30 hr, solar intensity was also maximum at this time. The efficiency was zero at 16:30 and 17:30 because at that the temperature difference of air was zero that's why efficiency equal to zero.

$\rightarrow$ Efficiency $\leadsto$ Solarintensity

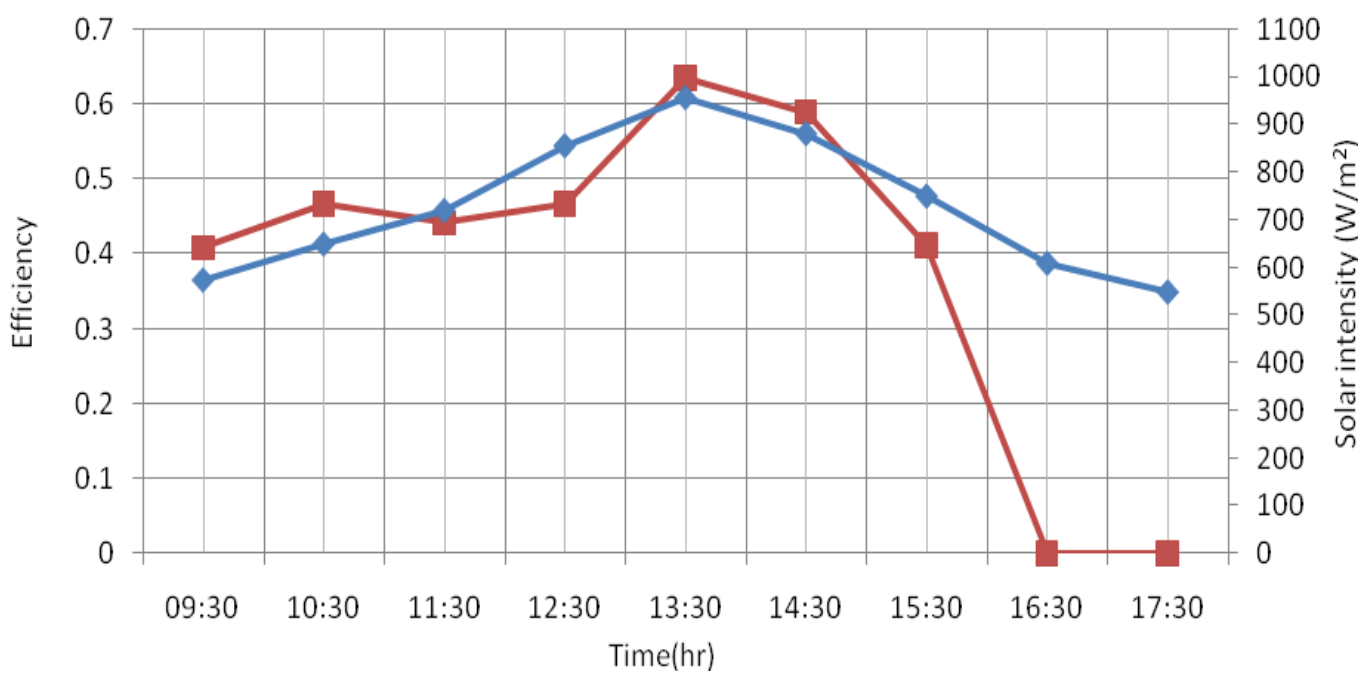

Figure 8. Variation of efficiency along with variation of solar intensity for solar air collector without reflector at $45^{\circ}$ tilt angle

The evacuated tube solar air collector was exposed to solar radiation one hour before the readings were taken. Figure 9 shows that solar radiation increases from 9:30 hr to $12: 30 \mathrm{hr}$ and after that it decreases. Initially obtained temperature difference of air is $5.1^{\circ} \mathrm{C}$ because of heat gained by fluid (water) inside the collector. It start increased up to 12:30 hr due to increase in solar intensity, after that it decreases with decrease in solar intensity. In this case, the maximum temperature difference of air was $12.3^{\circ} \mathrm{C}$ at $12: 30$ $\mathrm{hr}$, obtained at a faster rate as compared to the case of solar air heater without reflector at $45^{\circ}$ tilt angle of solar collector. But same problem of decreasing in thermosyphon phenomenon observed. 


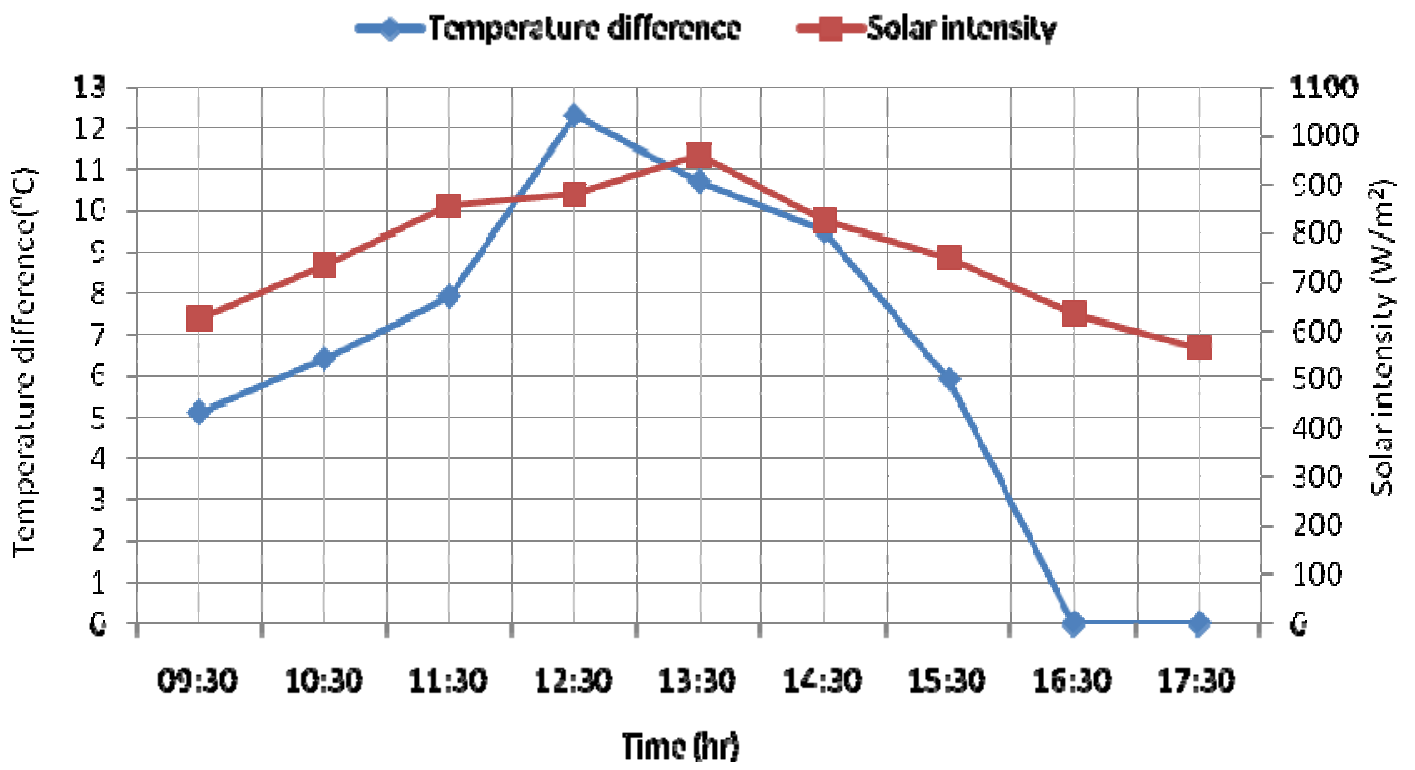

Figure 9. Variation of temperature difference of air along with variation of solar intensity for solar air collector with reflector at $45^{0}$ tilt angle

Figure 10 shows that solar radiation increases from 9:30 hr to $12: 30 \mathrm{hr}$ and after that it decreases. Initially obtained efficiency was 0.4009 because of temperature difference of the air. It start increased up to 12:30 hr due to increase in temperature difference of air, after that it decreased with decrease in temperature difference of the air. In this case, the maximum efficiency was 0.6846 at $12: 30 \mathrm{hr}$, obtained at a faster rate as compared to the case of solar air collector without reflector at $45^{\circ}$ tilt angle of solar collector. But same problem of decreasing in thermosyphon phenomenon observed.

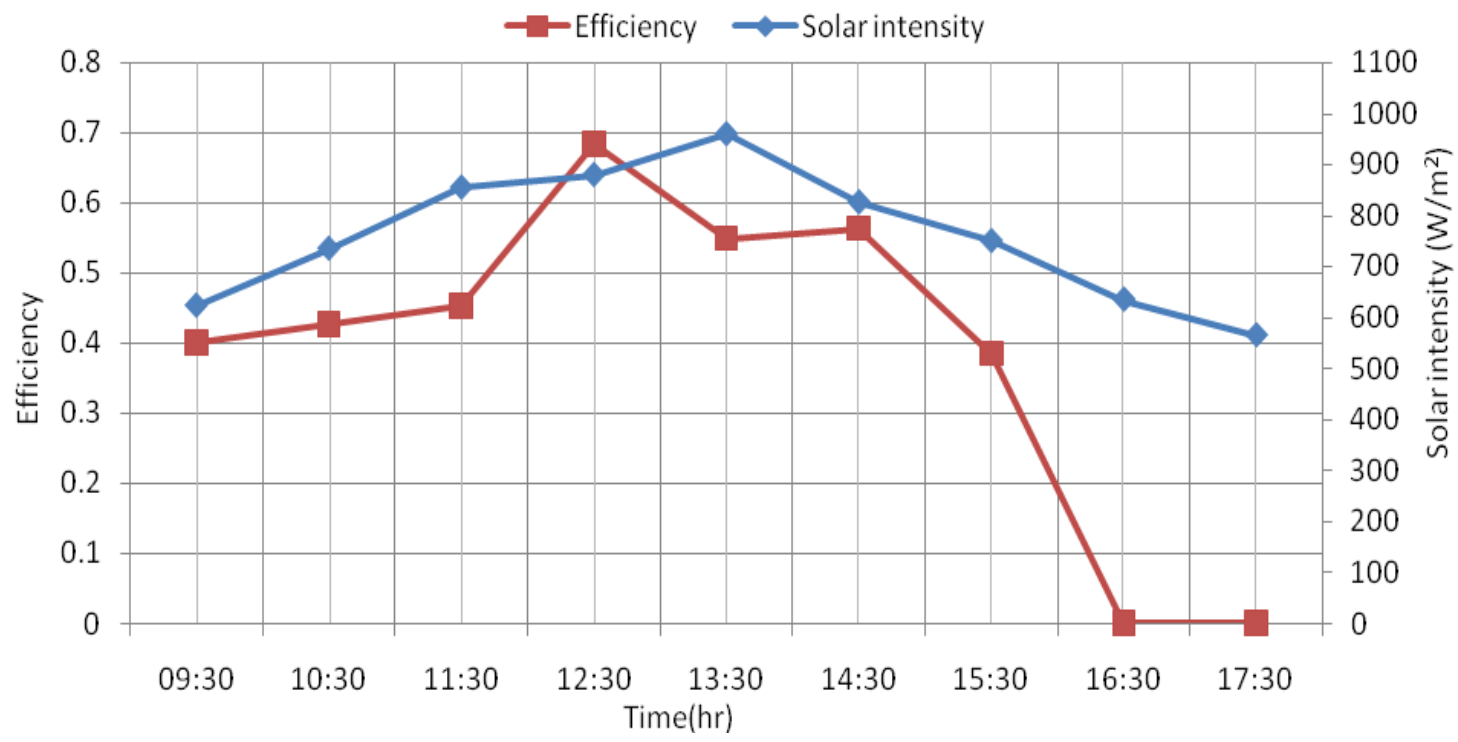

Figure 10. Variation of efficiency along with variation of solar intensity for solar air collector with reflector at $45^{\circ}$ tilt angle

Case 6.2: Evacuated tube solar air collector at 30 without and with reflector

The evacuated tube solar air collector was exposed to solar radiation one hour before the readings were taken. Figure 11 show that solar radiation increases from 9:30 hr to $13: 30 \mathrm{hr}$ and after that it decreases. Initially obtained temperature difference of air was $5.8^{\circ} \mathrm{C}$ because of heat gained by fluid (water) inside the collector. It start increased up to $13: 30 \mathrm{hr}$ due to increase in solar intensity, after that it decreased with decrease in solar intensity. The maximum temperature difference of air was $13.2^{\circ} \mathrm{C}$ at $13: 30$ 
$\mathrm{hr}$, solar intensity was also maximum at this time. In this case, the maximum temperature difference of the air is more than the case of solar air heater without reflector at $45^{\circ}$ tilt angle of solar collector.

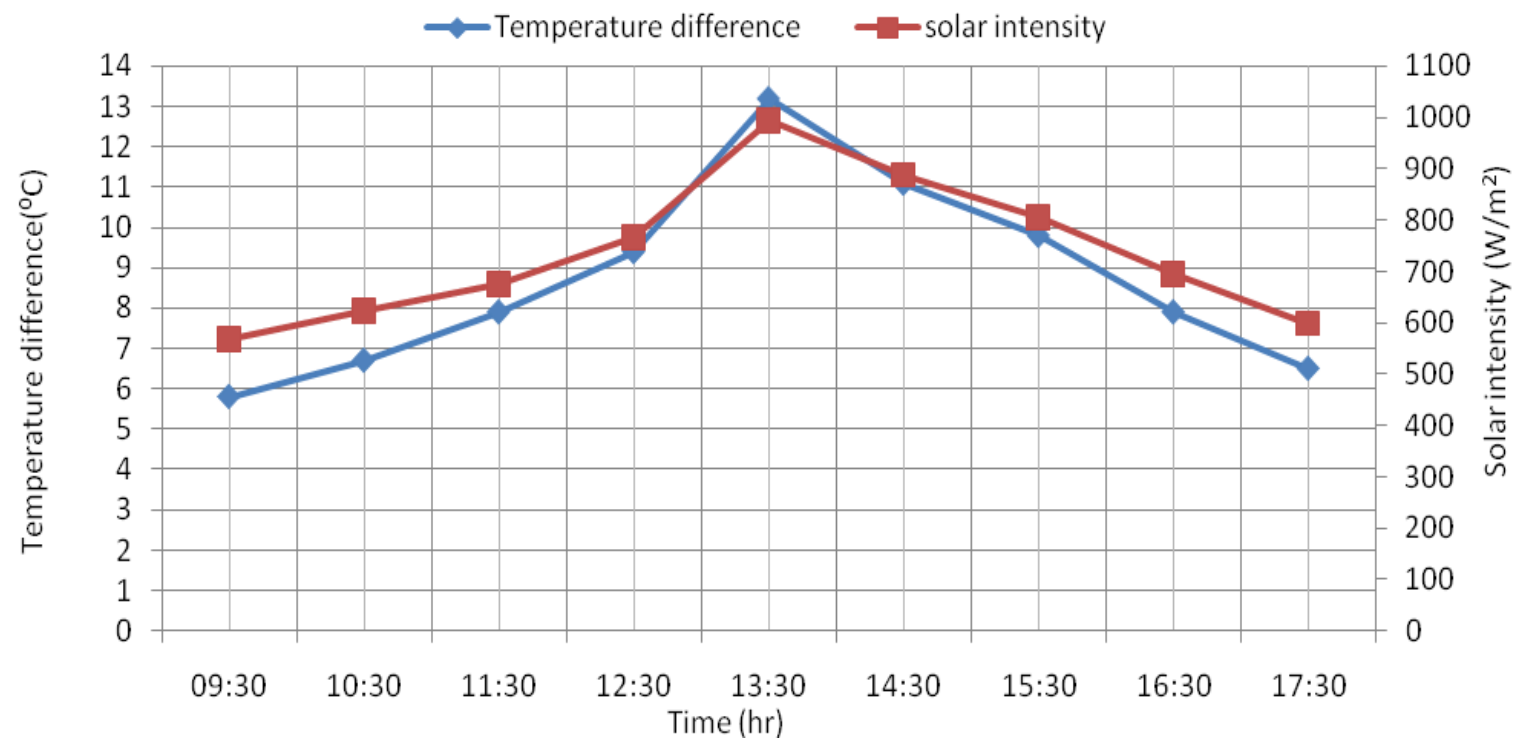

Figure 11. Variation of emperature difference of air along with variation of solar intensity for solar air collector without reflector at $30^{\circ}$ tilt angle

Figure 12 shows that solar radiation increases from 9:30 hr to 13:30 hr and after that it decreases. Initially obtained efficiency is 0.501 because of temperature difference of the air. It starts increases up to 13:30 $\mathrm{hr}$ due to increase in temperature difference of air, after that it decreases with decrease in temperature difference of the air. The maximum efficiency is 0.6498 at 13:30 hr, solar intensity is also maximum at this time. In this case, the maximum efficiency is more than the case of solar air heater without reflector at $45^{\circ}$ tilt angle of solar collector.

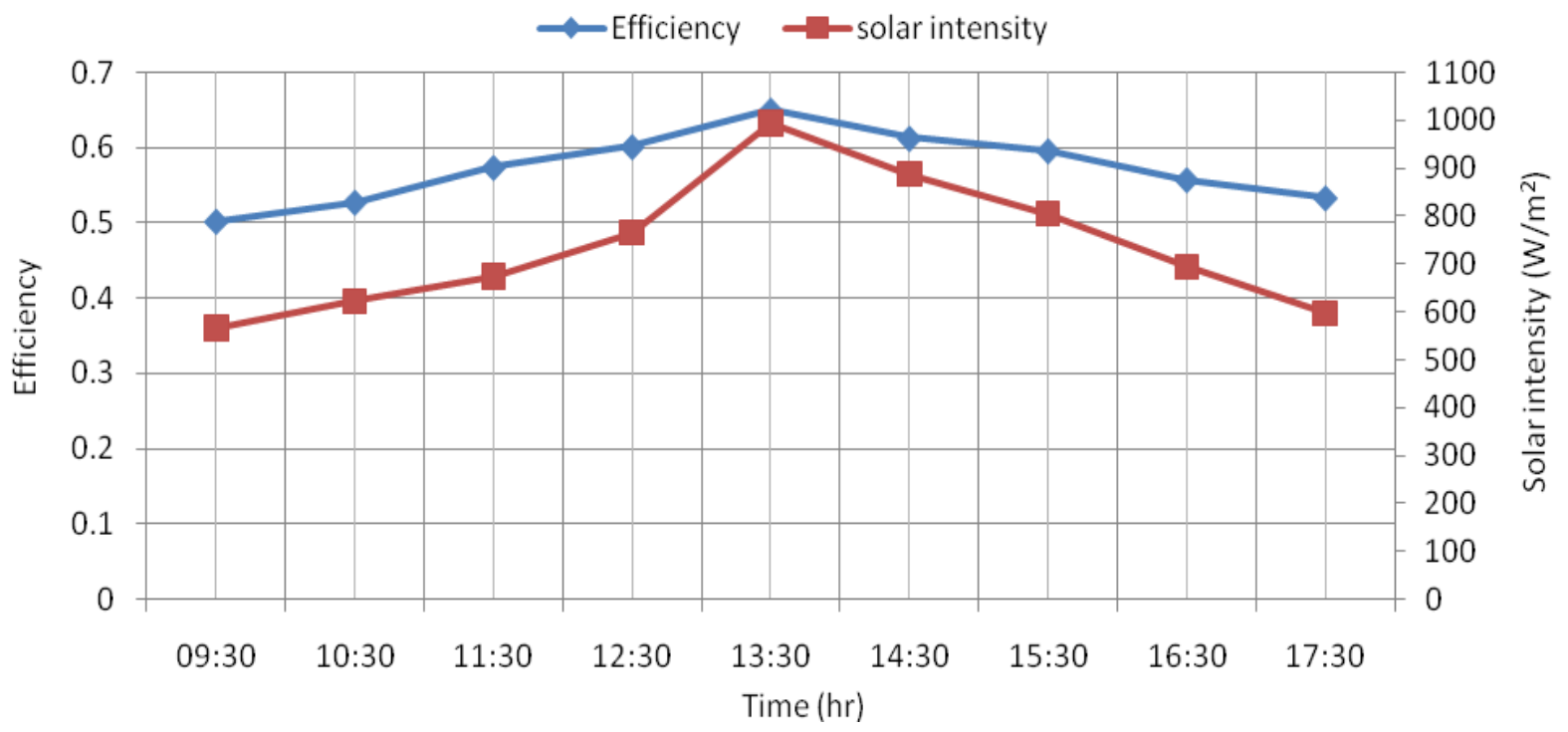

Figure 12. Variation of efficiency along with variation of solar intensity for solar air collector without reflector at $30^{\circ}$ tilt angle

The collector was exposed to solar radiation one hour before the readings were taken. Figure 13 shows that solar radiation increases from 9:30 hr to $12: 30 \mathrm{hr}$ and after that it decreases. Initially obtained temperature difference of air is $6.1^{\circ} \mathrm{C}$ because of heat gained by collector and then it starts increases up to $12: 30 \mathrm{hr}$ due to increase in solar intensity, after that it decreases with decrease in solar intensity. The maximum temperature difference of air is $13.7^{\circ} \mathrm{C}$ at $12: 30 \mathrm{hr}$, solar intensity is also maximum at this time. In this case, the maximum temperature difference is more than the previous cases. 


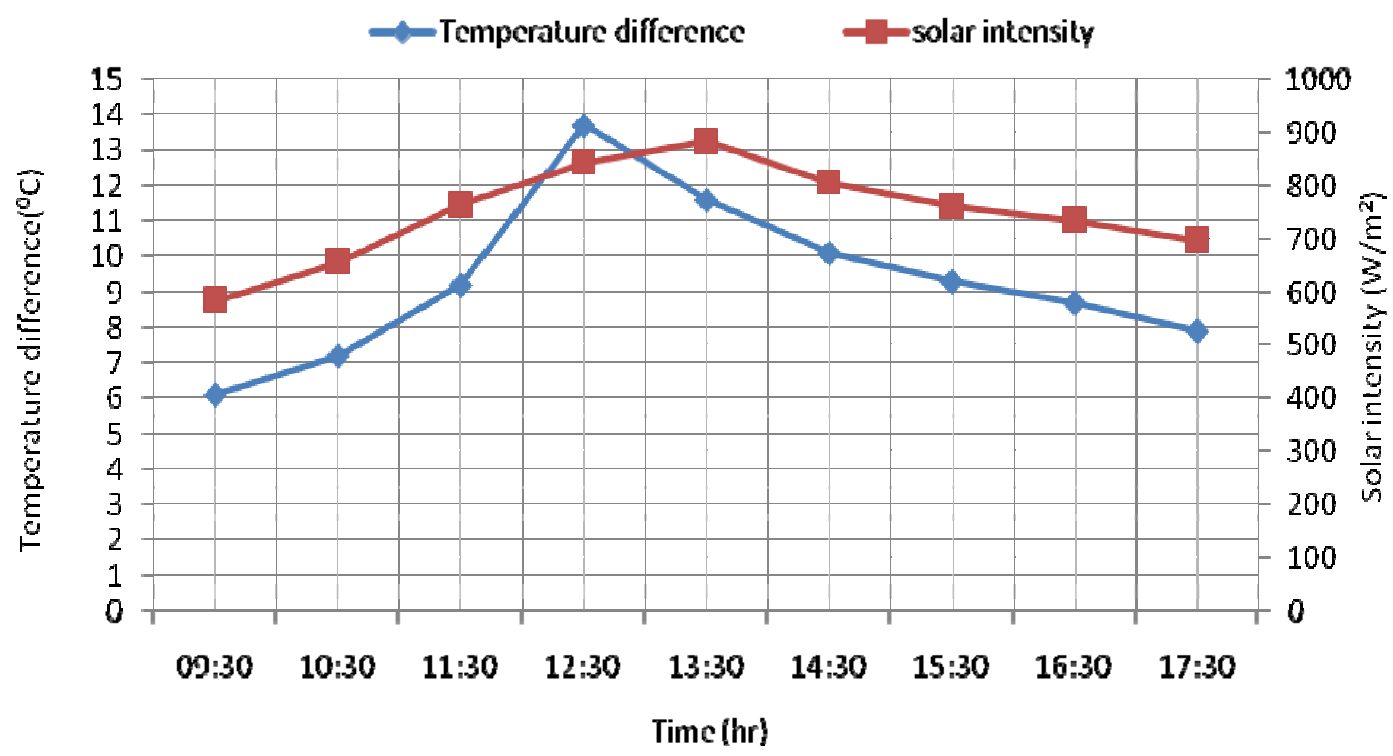

Figure 13. Variation of temperature difference of air along with variation of solar intensity for solar air collector with reflector at $30^{\circ}$ tilt angle

Figure 14 shows that solar radiation increases from 9:30 hr to 13:30 hr and after that it decreases. Initially obtained efficiency is 0.5112 because of temperature difference of the air. It starts increase up to 12:30 hr due to increase in temperature difference of air, after that it decreases with decrease in temperature difference. The maximum efficiency is 0.7959 at $12: 30 \mathrm{hr}$. In this case, the maximum efficiency is more than the previous cases.

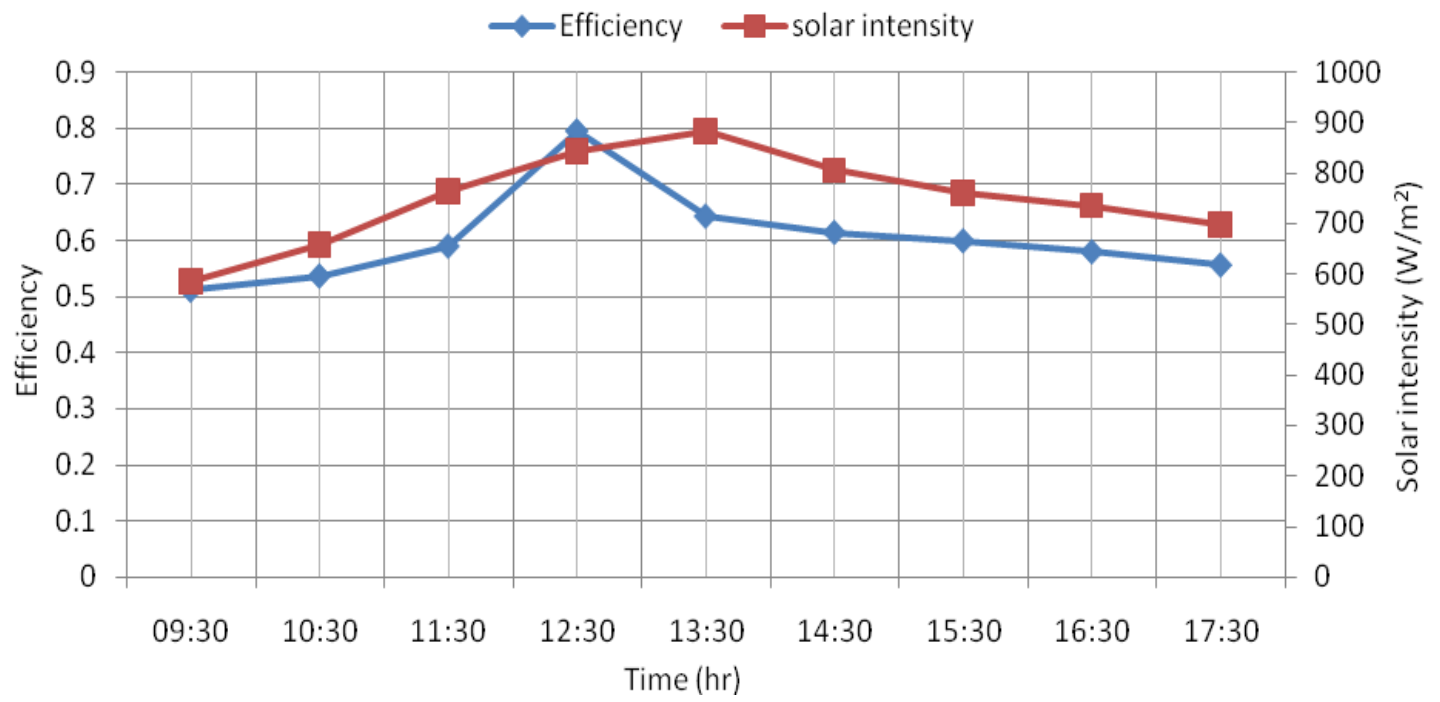

Figure 14. Variation of efficiency along with variation of solar intensity for solar air collector with reflector at $30^{\circ}$ tilt angle

\section{Conclusions}

Experimental results revealed that the collector tilt angle had significant effects on the thermal performance of evacuated tube solar air collector with reflector. Results showed that the temperature difference of the air and thermal efficiency of evacuated tube solar air collector at $30^{\circ}$ tilt angle is better as compare to the $45^{\circ}$ tilt angle. Results also showed that $30^{\circ}$ tilt angle with reflector had more thermal performance as compare to the $45^{\circ}$ angle with and without reflector. These indicated that steep collector tilt angle $\left(45^{\circ}\right)$ decrease the thermal performance of evacuated tube solar air collector and the thermosyphonic circulation 
phenomenon. The future aspects of evacuated tube solar air collector are regeneration of desiccants, solar cooking in evening with the help of phase change material. For domestic purpose: Evacuated tube solar air collector based on thermosyphon is used for room heating. For industrial purpose: Hot water generation, hot air generation, regeneration of desiccant wheel and also in air conditioning.

\section{Acknowledgements}

The authors are grateful to Mr. H.S. Chadha (M.D.), Sunson Energy Devices (P) LTD, New Delhi, India for their kind support in providing the evacuated tube solar air collector for the tests.

\section{Nomenclature}

A Surface area of solar collector $\left(\mathrm{m}^{2}\right)$

$\mathrm{C}_{\mathrm{P}} \quad$ Specific heat of air $(\mathrm{J} / \mathrm{Kg} \mathrm{K})$

$\mathrm{D} \quad$ Outer diameter of absorber tube (m)

I Solar Intensity $\left(\mathrm{W} / \mathrm{m}^{2}\right)$

L The length of absorber tube (m)

$\mathrm{m} \quad$ Mass flow rate of working fluid $\left(\mathrm{Kg} / \mathrm{s}, \mathrm{m}^{3} / \mathrm{hr}\right)$

$\mathrm{T}_{\text {out }} \quad$ Temperature of air at outlet ( $\left.\mathrm{C}\right)$

$\mathrm{T}_{\text {in }} \quad$ Temperature of ambient air ( C)

\section{Greek}

$\eta \quad$ Solar collector efficiency

\section{References}

Adsten, M., Perers, B. and Wackelgard, E., 2002. The influence of climate and location on collector performance. Renewable energy, Vol. 25, pp.499-509.

Ayompe, L.M., Duffy, A., Mc Keever, M., Conlon, M. and McCormack, S.J., 2011. Comparative field performance study of flat plate and heat pipe evacuated tube collectors (ETCs) for domestic water heating systems in a temperate climate. Energy, Vol. 36, pp. 3370-3378.

Bevill, V.D. and Brandt, H., 1968. A solar energy collector for heating air. Solar Energy, Vol. 12, Issue 1, pp.19-20, IN1,21-29.

Chow, T.T., Dong,Z., Chan, L.S., Fong, K.F. and Bai, Y., 2011. Performance evaluation of evacuated tube solar domestic hot water systems in Hong Kong. Energy and Buildings, Vol. 43, pp. 3467-3474.

Hossain, M.S., Saidur, R., Fayaz, H., Rahim, N.A., Islam, M.R., Ahamed, J.U. and Rahman, M.M., 2011. Review on solar water heater collector and thermal performance of circulating pipe. Renewable and Sustainable Energy reviews, Vol. 15, pp. 38013812.

Lamnatou, Chr., papanicolaou, E., Belessiotis, V. and Kyriakis, N., 2012. Experimental investigation and thermodynamic performance analysis of a solar dryer using an evacuated-tube air collector. Applied Energy, Vol. 94, pp. 232-243.

Morrison, G.L., Budihardjo, I. and Behnia, M., 2004. Water-in-glass evacuated tube solar water heaters. Solar Energy, Vol. 76, pp. 135-140.

Shariah, A., Al-Akhras, M.A. and Al-Omari, I.A., 2001. Optimizing the tilt angle of solar collectors. Renewable Energy 26 (2002) 587-598.

Sampathkumar, K. and Senthilkumar, P., 2012. Utilization of solar water heater in a single basin solar still—An experimental study. Desalination, article in press.

Sukhatme, S.P. and Nayak, J.K., 2008. Solar energy principles of thermal collection and storage. Third edition, Tata Mcgraw Hill Education Private Limited, New Delhi.

Garg, H.P. and Prakash, J., 2000. Solar energy fundamentals and applications. First revised edition, Tata Mcgraw Hill Education Private Limited, New Delhi.

Tang, R., Geo, W., Yu, Y. and Chen, H., 2009. Optimal tilt-angles of all-glass evacuated tube solar collectors. Energy, vol.34, pp. 1387-1395.

Tang, R., Yang, Y. and Geo, W., 2011. Comparative studies on thermal performance of water-in -glass evacuated tube solar water heaters with different collector tilt-angle. Solar Energy, Vol. 85, pp. 1381-1389.

Xu, L., Wang, Z., Yuan, G., Li, X. and Ruan, Y., 2012. A new dynamic test method for thermal performance of all-glass evacuated solar air collectors. Solar Energy, article in press.

Yadav,A. and Bajpai, V.K., 2012. Comparison of thermal performances of flat plate and evacuated tube solar air collector at different flow rates: experimental analysis. International Journal of Renewable Energy Technology. 
Yadav,A. and Bajpai, V.K., 2012. Thermal performance of one-ended evacuated tube solar air collector at different flow rates: experimental investigation. International Journal of Ambient Energy, Vol. 33, pp. 35-50.

Zhiqiang, Y., 2005. Development of solar thermal systems in China. Solar Energy Materials \& Solar Cells, Vol. 86, pp.427-442.

Zambolin, E. and Col, D.Del., 2012. An improved procedure for the experimental characterization of optical efficiency in evacuated tube solar collector. Renewable Energy, Vol.43, pp. 37-43.

Biographical notes

Vishal Dabra received his B.Tech. in mechanical engineering from Kurukshetra university in 2009 and M.Tech. in Mechanical Engineering from National Institute of Technology, Kurukshetra in 2012. Presently I am an Assistant Professor in Department of Mechanical Engineering, P.I.E.T Panipat, India.

Laxmikant yadav received his M.Tech. in Mechanical engineering from N.I.T Kuruksetrain 2012and Presently he is an Assistant Professor in Mechanical Engineering Department in A.K.G, Ghaziabad, India.

Dr. Avadhesh Yadav received his Ph.D. in thermal engineering from N.I.T, Kurukshetra. Presently he is an Assistant Professor in MED, N.I.T, Kurukshetra, India. He has more than thirty five papers in referred journals.

Received February 2013

Accepted June 2013

Final acceptance in revised form July 2013 